\title{
PENATALAKSANAAN BANTUAN HIDUP DASAR (BHD) PADA MASYARAKAT AWAM (SANTRI PONPES YAMBUUL HIKMAH) DI ANDONG BOYOLALI
}

\author{
Akhmad Rifai ${ }^{1}$, Muh Ilyas ${ }^{2}$ \\ 1,2 Poltekkes Kemenkes Surakarta Jurusan Keperawatan \\ Diterima : 10 Oktober 2018, Disetujui : 18 November 2018 \\ Email: fai_princeslo@yahoo.co.id
}

\begin{abstract}
Background: Heart disease is the number one cause of death, accounting for $39 \%$ of all deaths in the world. Basic Life Assistance (BLS) should be given to victims who suffer from stopping breathing, cardiac arrest, and bleeding. The purpose of this study was to determine the ability of Basic Life Support Skills (BLS) santri Ponpes Yambuul Hikmah in Andong Boyolali. Methods: This research is an experimental research with approach of Pre-Tes-Post Test Group design. through testing of research hypotheses. The population of this study is the people of cloud (santri Ponpes Yambul Hikmah) amounted to 50 respondents. Statistical test in pairs of groups using nonparametric Wilcoxon test. Result: Based on Wilcoxon test results it can be concluded that 50 respondents who Basic Life support Assistance (BLS) training can be drawn conclusion that the majority of santri have good knowledge in terms of emergency handling capability especially Basic Life Support with $p$ value 0,001 which means there is a difference that takes place between before and after training. Conclusion: put forward in this research is education and training BLS of santri continue to be held at other boarding school to improve the ability of BLS.
\end{abstract}

Keywords: Santri, management BLS

\section{PENDAHULUAN}

Survei Centers for Disease Control and Prevention (CDC) di United State ditemukan kasus henti jantung 31.689 selama 5 tahun (2005-2010) dan 33,3\% mendapatkan bantuan RJP dari bystander serta 3,7\% menggunakan Automated External Defibrillator atau AED (Bryan et al, 2011). Penyakit jantung merupakan penyebab kematian nomor satu, yakni penyebab 39\% dari seluruh kematian di dunia (Depkes RI, 2012), dimana 60\% diantaranya adalah penyakit jantung iskemik (WHO, 2012). Setelah penyakit jantung penyebab kematian terbanyak di dunia selanjutnya adalah penyakit Kanker 27\%, Diabetes Melitus 4\% dan penyakit pernafasan kronis, pencernaan, serta penyakit lain sebanyak 30\% (Priyana, Irmalita, 2011) Untuk membekali keterampilan para santri dalam Ketrampilan Bantuan Hidup Dasar (BHD) maka banyak institusi dan organisasiorganisasi mengadakan berbagai pelatihan BHD. Penelitian ini dilakukan untuk mengetahui tingkat kemampuan melakukan Bantuan Hidup Dasar (BHD) pada orang awam (Santri Ponpes Yambul Hikmah) Andong Boyolali.

\section{METODE PENELITIAN}

Penelitian ini merupakan penelitian eksperimental dengan pendekatan PreTes-Post Test Group design. melalui 
pengujian hipotesa penelitian. Populasi penelitian ini adalah para santri berjumlah 50 responden. Uji statistik pada penelitian ini adalah kelompok berpasangan menggunakan nonparametric Wilcoxon test.

\section{HASIL PENELITIAN}

Pengambilan data dilaksanakan pada bulan Juli 2017 yang terbagi dalam dua kelas. Dari total 50 responden yang di laksanakan di pondok pesantren Yambul Hikmah Andong Boyolali, didapatkan hasil pre test dan post test dapat digambarkan dalam bentuk table distribusi frekwensi sebagai berikut:

1. Analisis Univariat

Tabel 1. Distribusi Frekuensi Responden Berdasarkan Jenis Kelamin Responden

\begin{tabular}{llll}
\hline No & JenisKelamin & Frek & $\begin{array}{l}\text { Persentase } \\
(\%)\end{array}$ \\
\hline 1 & Laki - laki & 30 & 60 \\
2 & Perempuan & 20 & 40 \\
\hline & Jumlah & 50 & 100.0 \\
\hline
\end{tabular}

Tabel diatas menyajikan dari 50 responden, responden laki-laki berjumlah 30 orang $(60 \%)$ dan perempuan sebesar 20 orang (60\%). Sehingga mayoraitas responden adalah berjenis kelamin lakilaki.

Tabel 2. Distribusi Frekuensi Responden Berdasarkan Tingkat Pendidikan

\begin{tabular}{llll}
\hline No & Pendidikan & Frekuensi & $\begin{array}{l}\text { Persentase } \\
(\%)\end{array}$ \\
\hline 1 & MTs / SMP & 34 & 68.0 \\
2 & MA / SMA & 16 & 32.0 \\
\hline & Jumlah & 50 & 100.0 \\
\hline
\end{tabular}

Berdasarkan tabel diatas dari 50 responden, responden dengan pendidikan MTs/SMP yaitu 34 orang (68\%) dan Pendidikan MA/SMA sebanyak 16 orang (32\%). Sebagian besar responden pada pelatihan ini berpendidikan MTs/SMP.
Tabel 3. Distribusi Frekuensi Responden Berdasarkan Kelompok Umur

\begin{tabular}{llll}
\hline No & Umur & Frekuensi & $\begin{array}{l}\text { Persentase } \\
(\%)\end{array}$ \\
\hline 1 & 15-20 Tahun & 33 & 66.0 \\
2 & 21-25 Tahun & 14 & 28.0 \\
3 & 26-30 Tahun & 3 & 6.0 \\
\hline & Jumlah & 50 & 100.0 \\
\hline
\end{tabular}

Berdasarkan tabel tersebut dari 50 responden, responden dengan umur 15-20 tahun yaitu 33 orang $(66 \%)$ sedangkan umur 21-25 tahun sebanyak 14 orang (28\%) dan dengan umur 26-30 tahu sebanyak 3 orang (3\%). Sebagian besar umur responden pada pelatihan BHD ini adalah di antara 15-20 tahun.

Tabel 4. Tingkat Kemampuan Responden sebelum dan sesudah Pelatihan BHD

\begin{tabular}{llllll}
\hline Variabel & & \multicolumn{3}{c}{ Pelatihan BHD } \\
\hline & & Pre & Post \\
\hline Tingkat & n & $\%$ & n & $\%$ \\
kemampuan & 24 & 48 & 0 & 0 \\
BHD & Kurang & 20 & 40 & 3 & 6 \\
& Cukup & 6 & 12 & 21 & 42 \\
& Baik & 0 & 0 & 26 & 52 \\
\hline
\end{tabular}

Tabel diatas menyajikan hasil dari 50 responden, dengan tingkat kemampuan BHD sebelum pelatihan buruk 24 responden $(48 \%)$ kurang 20 responden (40\%) cukup 6 responden (12\%) dan hasil sesudah dilakukan pelatihan dengan hasil buruk tidak ada atau o\% dan kurang 3 responden (6\%) cukup 21 responden (42\%) dan dengan hasil baik 26 responden $(52 \%)$. 


\section{Analisis Bivariat}

Tabel 5. Hasil analisis uji Willcoxon tingkat kemampuan responden Sebelum dan Sesudah dilakukan pelatihan BHD

\begin{tabular}{lcccc}
\hline \multicolumn{1}{c}{ Variabel } & Med & $\begin{array}{c}\text { Min- } \\
\text { Max }\end{array}$ & $p$ \\
\hline $\begin{array}{l}\text { Tingkat } \\
\text { kemampuan } \\
\text { responden } \\
\text { sebelum }\end{array}$ & 0 & 2 & $1-2$ & \\
$\begin{array}{l}\text { Pelatihan BHD } \\
\begin{array}{l}\text { Tingkat } \\
\text { kemampuan } \\
\text { responden } \\
\text { sesudah } \\
\text { pelatihan BHD }\end{array}\end{array}$ & 0 & 4 & $3-4$ & \\
\hline
\end{tabular}

Berdasarkan tabel diatas dari 50 responden, Tingkat kemampuan BHD sebelum pelatihan dengan hasil median 2 dan minimal 1 dan maksimal 2 sedangkan pada Tingkat kemampuan BHD sesudah pelatihan dengan hasil median 4 dan minimal 3 dan maksimal 4. Adapun hasil dari $P$ value 0,001 yang artinya ada perbedaan yang signifikan antara sebelum dan sesudah dilakukan pelatihan BHD

\section{PEMBAHASAN}

Tempat atau lokasi penelitian ini adalah di Ponpes Yambul Hikmah kecamatan Andong Boyolali. Sebelum pemberian materi Bantuan Hidup Dasar (BHD) pada responden, terlebih dahulu dilakukan pre test untuk mengukur tingkat kemampuan responden. Pelaksanaan pelatihan responden di bagi menjadi 2 kelas, setiap kelas terdiri dari 25 responden. Hasil dari penelitian ini didapakan bahwa jumlah responden sebanyak 50 responden yang terdiri lakilaki dan permpuan dan sebagian besar berjenis kelamin laki-laki atau $60 \%$, umur rata-rata diantara 15 sampai dengan 20 tahun, sedangkan pendidikan rata-rata MTs/SMP sebear $68 \%$. Hasil penelitian menunjukkan bahwa dari 50 responden, terdapat 3 orang $(6 \%)$ dengan tingkat kemampuan kurang, tingkat kemampuan cukup ada 21 orang (42\%) dan tingkat kemampuan baik ada 26 orang (52\%). Hasil uji hipotesis menggunakan uji non parametric Wilcoxon , Tingkat kemampuan melakukan Bantuan Hidup Dasar (BHD) dengan nilai $\mathrm{p}$ value = 0,001 yang berarti bahwa setelah dilakukan pelatihan bantuan hidup dasar ada perbedaan yang bermakna terhadap Tingkat kemampuan melakukan Bantuan Hidup dasar. Pengetahuan tentang BHD akan meningkatkan pengetahuan individu tentang mengidentifikasi tanda-tanda korban yang harus diberikan BHD, caracara melakukan tahapan BHD dan juga mengetahui tandatanda korban yang telah dalam keadaan pulih atau tidak terselamatkan. Pengetahuan tentang BHD ini tentunya dapat mengurangi kematian. Hal ini sesuai dengan hasil penelitian yang dilakukan oleh Rau (2007)

\section{KESIMPULAN DAN SARAN}

Sesudah diberikan materi tentang Bantuan Hidup dasar (BHD) 3 orang (6\%) dengan tingkat kemampuan kurang, tingkat kemampuan cukup ada 21 orang $(42 \%)$ dan tingkat kemampuan baik ada 26 orang $(52 \%)$.

Ada pengaruh yang signifikan antara sebelum dan sesudah dilakukan pelatihan BHD. Penanganan henti nafas dan henti jantung harus di miliki oleh setiap orang baik orang awam,awam khusus terlebih tenaga kesehatan sehingga jika sesorang menemukan penyitas yang mengalami henti nafas dan henti jantung dapat melakukan BHD dengan benar 
DAFTAR RUJUKAN

Bryan, et al. 2011. Out-of-hospital cardiac arrest surveillance-cardiac arrest registry to enhance survival (CARES), united states.Morbidity and Mortality Weekly Report Surveillance Summaries / Vol. 60 / No. 8

Priyana, Irmalita (2011). Analisis Etik Terkait Resusitasi Jantung Paru. Jakarta.

UNYARSI

Rau, R. (2007). Skripsi Hubungan Pengetahuan Perawat dengan
Kemampuan Melakukan Bantuan Hidup Dasar Di IRD RSUP Kandou Manado.

World Health Organization (WHO). 2007. Risk Reduction and Emergency Preparedness. Printed by the WHO Document Production Services, Geneva,Switzerland.

World Health Organization. Diabetes. http://www.who.int/topics/diabetes_ mellitus/en/ (accessed 4 February 2018). 